\title{
“Am I Man Enough?”: Diskriminasi Terhadap Identitas Transpria Muda (Studi Analisis Video YouTube Trans Men Talk Indonesia)
}

Himas Nur Rahmawati

Program Studi Kajian Budaya dan Media Universitas Gadjah Mada

himasnur6@mail.ugm.ac.id

\begin{abstract}
Discourse contestation around youth in Indonesia still rarely touches issues related to gender minority identities, transman (transgender man) is one of them. This research discusses the complexity of the problems and situations of discrimination experienced by young transmen in Indonesia. The research was conducted by analyzing the YouTube video of Trans Men Talk Indonesia entitled "Transmen Indonesia: We are Exist, Real and Deserved to be Happy too. Part 1. " This community, which was founded by young transmen, used YouTube as an arena for self-articulation and a performative space to show their agency. This study uses a qualitative content analysis method by selecting thematic narratives and visual texts. The findings are young transmen experiencing discrimination which can be described through three domains, namely in (1) dating life; (2) occupation, and; (3) scarcity of safe space. Collective solidarity for the transmen community is an urgency. This effort is made in order to create an inclusive space that is commensurate with those who are often carried out by the power of cisnormativity.

Keywords: Young Transman | Transgender Discrimination | Trans Men Talk Indonesia | Queer Studies | Cisnormativity
\end{abstract}

\section{PENDAHULUAN}

Wacana kaum muda di Indonesia masih terbatas dalam menyentuh perspektif identitas gender di luar tataran cisnormativitas. Cisnormativitas merupakan sistem kuasa yang mengasumsikan bahwa cisgender adalah sesuatu yang natural dan ahistoris (Collier dan Daniel 2019). Istilah cisgender merujuk pada identitas gender yang sesuai dengan harapan masyarakat normatif. Contohnya, individu yang memiliki karakteristik seks betina (female) saat lahir, diharuskan mengidentifikasi gendernya sebagai perempuan (National LGBTQIA+ health
Education Center 2020). Praktik cisnormativitas ini tak lain merupakan penghapusan realitas pada kondisi keragaman gender. Salah satu kelompok muda di luar biner gender yang mengalami tekanan cisnormativitas, dan perjuangannya sunyi dibicarakan adalah transpria.

Sebagai bagian dari kelompok minoritas gender, transpria muda tereksklusi dari kontestasi wacana seputar pemuda. Padahal mereka juga memiliki sekian persoalan yang sepadan, dan dimungkinkan memiliki kompleksitas yang lebih beragam. Perkara konsumerisme, 
subkultur, kepanikan moral, agensi dan resistensi telah lekat dan terkait dengan konsep kaum muda. Konsep pemuda queer (queer youth) selanjutnya memiliki potensi menawarkan resonansi yang lebih dalam kala hendak memahami sifat transgresif pemuda (Pullen 2014).

\section{Trans Men Talk Indonesia} merupakan komunitas yang didirikan oleh transpria muda di Indonesia sejak September 2020. Pada perkembangannya mereka memiliki kanal YouTube yang mulai aktif sejak 4 Maret 2021. Mereka memproduksi wacana yang spesifik terkait identitas transpria muda beserta konteks politik dan sosio kultural Indonesia yang melingkupi eksistensi identitas ini. Kanal YouTube Trans Men Talk Indonesia telah menghasilkan delapan konten video dengan total 1.066 kali ditonton, serta memiliki pelanggan (subscribers) sejumlah 54 akun.

\section{Kehadiran Trans Men Talk} Indonesia merupakan bentuk narasi tanding atas represifnya cisnormativitas yang terlembaga di Indonesia. Komunitas ini memproduksi video-video yang menawarkan ruang pembacaan yang lebih inklusif perihal keragaman perasaan dan pengalaman transgender, khususnya transgender laki-laki. Video-video tersebut juga merupakan sesuatu yang organik karena disuarakan langsung oleh mereka yang menghayati dan mengalami pergulatan identitas transpria muda.

Pemuda trans (trans youth), dipaparkan O'Neill tak jauh berbeda dengan kaum muda lainnya yang mendialogkan YouTube sebagai ruang berbagi dan berproses kreatif. "Trans youth are no different, seeking an environment in which they feel comfortable and where they can produce personalized representational content" (2014: 35). YouTube sebagai salah satu media baru menjadi saluran eksplorasi artistik bagi transpria muda untuk mengekspresikan diri, serta menuangkan gagasan atas keberagaman identitas gender. Jenzen (dalam Tortajada,
2020: 4) menyatakan bahwa YouTube menjadi salah satu ruang utama aktivisme LGBTIQ (Lesbian, Gay, Biseksual, Transgender, Interseksual, Queer) Hal tersebut sejalan dengan kian aktifnya wacana transgender dikenali sebagai subjek dalam budaya populer (Lovelock 2017).

Namun kebebasan ruang juga melahirkan keterbukaan atas masifnya kekerasan. Ujaran kebencian terhadap transgender yang mengungkapkan identitas dirinya di ruang publik, termasuk YouTube, juga menguat. Meski begitu, YouTube tetap menjanjikan kemudahan aksesibilitas bagi kelompok marginal. Ketiadaan proses administrasi normatif, misalnya persyaratan dokumen identitas diri yang dilegitimasi negara, membuat transpria dapat menjadi pengguna dan memiliki akun di media digital. YouTube menjadi salah satu saluran populer bagi individu-individu non-normatif (Raun 2016) untuk merepresentasikan diri dan memperluas visibilitas.

Meski tak selalu mengarah pada validasi, namun visibilitas merupakan strategi penting untuk menciptakan rasa identitas bersama dan membangun support system. Ketika identitas gender yang sangat jarang dibicarakan menjadi "tampak", maka akan pula tumbuh ruang untuk meningkatkan kesadaran atas identitas tersebut. Individu-individu yang menghayati pun akan lebih dikenal, diwakili dan dipahami oleh masyarakat luas (Hayfield, 2020: 17). Ketika identitas transpria mulai diwacanakan, maka visibilitas atas hak berkehidupan untuk komunitas ini turut mengikuti, termasuk visibilitas atas daftar diskriminasi yang selama ini terjadi.

Trans Men Talk Indonesia mendialogkan YouTube sebagai arena artikulasi diri dan ruang performatif ke dalam pertarungan wacana yang kerap absen ketika membincang persoalan pemuda. Persoalan-persoalan yang dibahas dalam kanal YouTube Trans Men Talk 
Indonesia berkisah seputar perjalanan dalam memperjuangkan kehidupan transpria di Indonesia. Video mereka menggambarkan kompleksitas permasalahan anak muda melalui perspektif gender minoritas, di antaranya perkara ; (1) kehidupan kencan; (2) pekerjaan, serta; (3) ruang aman. Ketiga topik utama khas pemuda tersebut secara komprehensif dituangkan melalui video YouTube Trans Men Talk Indonesia yang berjudul "Transpria Indonesia: Kami Ada, Nyata dan Berhak Juga Bahagia. Part 1."

Video berdurasi 35 menit tersebut kali pertama diunggah pada 8 Maret 2021. Hingga tulisan ini disusun, video telah ditonton sebanyak 356 kali dengan total 9 komentar, 31 suka dan 0 tidak suka. Video tersebut mengisahkan perjalanan Matteo Aaron, seorang transpria muda, yang mengalami kebimbangan atas eksistensi dirinya yang dikonstruksikan tak sesuai dengan masyarakat normatif. Keyakinan Aaron sebagai laki-laki berbenturan dengan performativitas gender yang cisnormatif sematkan terhadap sosok laki-laki. Perawakan tubuh yang besar, dada yang bidang, suara yang berat, serta wajah yang berkumis dan bercambang menjadi identifikasi normatif seorang laki-laki. Pada permasalahan tersebut, Aaron kerap mengalami diskriminasi sebab ia tak "terlihat" sebagai laki-laki yang dikehendaki masyarakat. Kondisi ini dikisahkan pada kutipan deskripsi video mereka.

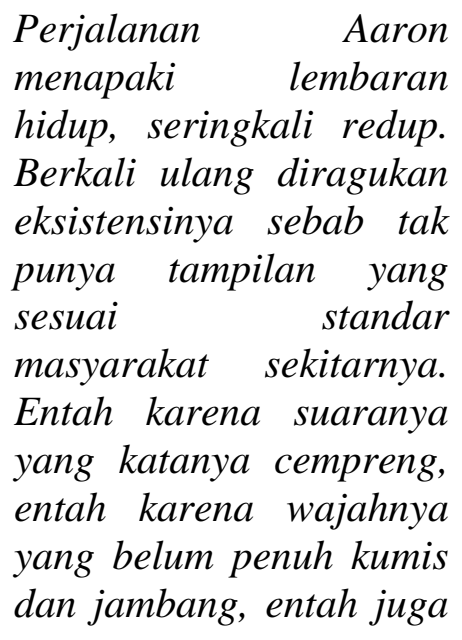

karena tubuhnya yang menurut mereka adalah tubuh yang dimiliki oleh perempuan (Trans Men Talk Indonesia 2021).

Ketiadaan validasi dari lingkungan sekitar berimplikasi pada perkara romansa. Kehidupan kencan yang menjadi salah satu persoalan khas kaum muda, dialami pula oleh transpria. Namun problema yang mesti dihadapi transpria muda kian kompleks, termasuk ketika pasangan yang berelasi dengan transpria muda, tak memiliki pemahaman inklusif tentang keragaman gender. Aaron dibenturkan pada keraguan apakah ia harus mengungkapkan identitasnya, sementara hal yang sama tak pernah dialami oleh kaum muda lain yang merupakan cisgender. Selain itu, perkara melela (coming out) bukanlah suatu kewajiban. Pengungkapan atas identitas diri mesti dilakukan secara sukarela dengan memertimbangkan kondisi keamanan dan kenyamanan individu tersebut.

Perkara identitas yang tidak dilegitimasi negara berimplikasi pula ketika hendak mencari pekerjaan. Transpria muda mengalami diskriminasi dalam lingkungan pekerjaan, sebab tidak semua pekerjaan formal, maupun informal ramah terhadap transgender. Kisah Aaron dalam video YouTube Trans Men Talk Indonesia juga menggambarkan perjuangan keseharian yang harus dilalui oleh transpria muda di Indonesia. Diskriminasi dalam ruang publik, Aaron alami ketika diharuskan berurusan dengan dokumen administrasi, seperti KTP (Kartu Tanda Penduduk), SIM (Surat Izin Mengemudi), kartu jaminan kesehatan, ijazah sekolah, maupun dokumen-dokumen lain yang mencantumkan nama dan gender yang bukan milik Aaron. Ketiadaan ruang aman sebagai gender minoritas, dirasakan pula oleh karakter Aaron, bahkan kala hendak ke toilet maupun warung makan. Aaron harus mengelola disforia gender yang ia alami ketika orang-orang memandangnya dengan 
tatapan transfobik ${ }^{1}$ dan memanggilnya dengan pronomina yang merujuk pada sapaan gender yang bukan miliknya (misgendering).

Berdasar pada latar permasalahan diatas, penelitian ini mengajukan rumusan pertanyaan: bagaimana diskriminasi yang dialami oleh identitas transpria muda di Indonesia dalam video YouTube Trans Men Talk Indonesia?. Penelitian ini berupaya memahami permasalahan pemuda melalui sudut pandang gender minoritas. Diharapkan penelitian ini bermanfaat dalam menawarkan wacana yang lebih beragam atas kajian queer di Indonesia. Penelitian ini diharapkan pula dapat menjadi sumbangsih ruang aman serta bentuk solidaritas kolektif bagi transpria muda serta komunitas queer di Indonesia secara keseluruhan.

Pada proses penelusuran terkait tinjauan pustaka, peneliti memilih membaca penelitian-penelitian di Indonesia tentang transpria. Hal ini berkaitan untuk memahami wacana Transpria dalam konteks Indonesia yang ada dalam publikasi ilmiah. Pustaka pertama adalah "I Post Therefore I am" Sebuah Kajian Budaya Populer tentang Social Media dan Visibilitas Transgender Female to Male (Transman) di Ruang Publik (Setyono 2016). Penelitian tersebut melihat media sosial didialogkan oleh dua subjek transpria di Indonesia. Setyono mewacanakan pendekatan SOGIESC (Sexual Orientation, Gender Identity and Expression, and Sex Characteristics) dalam mengurai perspektif identitas gender. Penelitian juga mendialogkan teori Uses and Gratification dalam kaitannya dengan penggunaan media sosial. Metode yang dilakukan adalah wawancara mendalam dan digital ethnography. Penelitian Setyono menghasilkan simpulan bahwa media sosial

\footnotetext{
${ }^{1}$ Transfobik atau Transfobia merupakan ketakutan irasional atau kebencian terhadap transgender dan atau transeksual (Israel dan Tarver dalam Pyne 2011). Praktik kebencian ini berakibat pada termarginalisasinya komunitas trans pada berbagai
}

tidak hanya sekedar hiburan tetapi media yang dapat meningkatkan visibilitas di ruang publik. Kekosongan celah pada pembacaan terkait konteks kaum muda beserta diskriminasi yang mesti dihadapi oleh transpria muda di Indonesia inilah yang diwacanakan dalam penelitian ini.

Pustaka selanjutnya adalah Representasi Tubuh Transman dalam Film 3 Generations (Firmansyah, Priyatna, dan Rahayu 2018). Penelitian Firmansyah et al. mewacanakan salah satu film dalam mengurai permasalahan transpria. Fokus yang dibahas adalah ekspresi maskulinitas non-hegemonik yang dilakukan oleh transpria dalam film 3 Generations. Melalui metode kualitatif dan deskriptif analitik, penelitian Firmansyah et al. memaparkan performativitas tokoh transpria dalam mengekspresikan dirinya melalui tindakan transisi. Penelitian tersebut memiliki celah dengan tidak mengurai bahwa transisi yang diupayakan oleh transgender tidak selalu berupa transisi medis atau fisik, melainkan bisa pula secara sosial maupun legal. Kekosongan dalam mempertanyakan konteks sosiokultural, serta diskriminasi seperti apa yang melatari upaya transisi transpria inilah yang kemudian peneliti lengkapi dalam penelitian ini.

Berdasar pada tinjauan di atas, penelitian di Indonesia yang memiliki fokus kajian pada transpria masih terbatas. Masih minim pula kompleksitas serta keragaman pembahasan yang dilakukan ketika mewacanakan transgender pria. Penelitian ini merupakan kebaruan dari pustakapustaka sebelumnya dalam menawarkan wacana tentang pengalaman kaum muda dari perspektif transpria, beserta sederetan pergulatan dan perjuangan mereka selama mengalami diskriminasi di negeri sendiri.

aspek berkehidupan. Represi, diskriminasi, hingga penghapusan orang-orang trans (the erasure of trans people) dalam ruang-ruang publik terjadi, contohnya pada kebijakan kelembagaan dan institusional (Pyne, 2011: 131). 


\section{IDENTITAS TRANSPRIA MUDA SEBAGAI SEBUAH SUBKULTUR}

Wacana transpuan di Indonesia lebih populer bila dikomparasikan dengan wacana transpria. Ketika berbicara tentang transgender, maka rujukan yang berkelindan lebih condong pada eksistensi transpuan. Ihwal ini serupa ketika membincang LGBTIQ, maka rujukan yang kerap disematkan adalah terhadap komunitas lesbian, gay, waria dan atau transpuan. Padahal LGBTIQ sebagai sebuah payung besar identitas, berbasis pada SOGIESC yang beragam. Masingmasing spektrumnya memiliki kejamakan pengalaman personal dan kolektif yang berbeda-beda, serta tak bisa direpresentasikan oleh satu atau dua identitas yang lain.

Salah satu bagian dari spektrum LGBTIQ tersebut adalah transpria. Transpria merupakan identitas gender dimana seorang individu menghayati dirinya sebagai laki-laki dan memiliki karakteristik seks betina (female) yang ditetapkan saat lahir. Definisi dari identitas gender ini juga sangat terbuka dan dimungkinkan berbeda pada tiap-tiap individu. Pada latar perjalanannya, gender ini memiliki ragam terminologi, baik dari luar negeri serta dalam negeri, seperti transgender FTM (Female to Male), trans sexual man, trans masculine, trans man, trans boy, trans laki-laki, dan transpria. Sangat dimungkinkan bahwa deretan label tersebut adalah sedikit dari tak terhingganya kategori-kategori label di seluruh dunia untuk mendefinisikan gender subordinat ini. Masing-masing kategori tersebut menjadi valid ketika individu trans sendiri yang memilih dan mengidentifikasi dirinya dengan label identitas yang ia rasa aman dan nyaman.

Namun istilah-istilah yang mengakomodasi identitas gender transpria belum pula menjadi wacana mayor, termasuk dalam kajian queer di Indonesia. Livia dan Hall (dalam Agustine, Sutrisno dan Candraningrum, 2015: 52) menuturkan bahwa subjektivitas penamaan diri merupa urgensi, karena ada keterbatasan bahasa dalam mendefinisikan orang-orang yang mengkategorikan dirinya Queer. Kebernamaan kemudian menjadi penting sebagai wujud eksistensi dan validasi atas tiap-tiap ragam pengalaman dan perasaan manusia.

Gerakan perjuangan dan advokasi yang berfokus pada transpria muda di Indonesia pun terbilang baru, beberapa diantaranya adalah Transhition Collective, Transmen Ngehe Support Group, Transmen Indonesia, Persatuan Priawan Indonesia, serta Trans Men Talk Indonesia. Pada Agustus 2014, para transpria muda menyelenggarakan Transmen Camp \#1 sebagai ruang belajar bagi transpria yang pertama kali diselenggarakan secara kolektif (Ardiansyah 2015). Tindak lanjut dari acara tersebut adalah diadakannya Transmen Camp \#2 pada 9-13 Agustus 2015 dan diikuti oleh 22 transpria dari 8 provinsi yang berbeda, yakni Aceh, Sumatera Utara, Kalimantan Timur, Jawa Barat, Jawa Tengah, Jawa Timur, DI Yogyakarta, dan DKI Jakarta. Momen tersebut menandai pula sejarah terselenggaranya Pertemuan Nasional Transmen Indonesia pada 14-16 Agustus 2015 di Yogyakarta.

Namun ruang kolektif transpria muda yang baru saja hidup dan mengorganisasikan diri tersebut, terhantam oleh isu anti-LGBTIQ crackdown sejak 2016 silam. Laporan Human Rights Watch (2016) dalam "Permainan Politik Ini Menghancurkan Hidup Kami”: Kelompok LGBT Indonesia dalam Ancaman menjelaskan bahwa muncul sederetan ancaman terhadap komunitas queer yang dilakukan oleh pejabat publik, komisi negara, kaum Islamis militan, dan organisasi keagamaan arus utama (2016: 1). Peningkatan retorika anti-LGBTIQ, termasuk oleh media arus utama membuat situasi kian tidak aman, baik secara fisik maupun mental, bagi individu queer. 
Kepanikan moral sejak 2016 tersebut berimbas pula pada gerakan transpria muda. Banyak dari mereka yang terkena dampak tindak represi dan persekusi, hingga memutuskan untuk vakum dari gerakan (Shean 2020).

Perjuangan transpria muda untuk kembali bangkit dan berorganisasi setelah sempat habis-habisan dihajar kuasa struktural, tidaklah mudah. Mereka dihadapkan untuk menjadi agen yang melakukan perlawanan atas kerentanannya sebagai identitas minoritas dan sebagai bagian dari kaum muda. Sutopo (2016: 502) mengemukakan bahwa pemuda merupakan subjek yang senantiasa bernegosiasi. Kondisi tersebut dimungkinkan karena terdapat relasi kuasa yang tak sepadan antara pemuda dan kondisi sosio kultural yang berlaku. Pada kasus transpria muda, sebagai kesatuan subkultur yang berkelindan, mereka memiliki pengalaman marginalisasi yang berlapis. Transpria muda sebagai sebuah subkultur berada dalam posisi subordinat dan kontra hegemonik atas kukuhnya formasi budaya dominan, yakni cisnormativitas.

Perjuangan untuk kembali memunculkan semangat perlawanan perlahan diinisiasi kembali secara kolektif oleh transpria muda. Serupa penjelasan Blackman (dalam Sutopo, 2016: 502), kelompok subkultur memiliki resistensinya dalam menghadapi gempuran budaya yang lebih luas dalam struktur sosial masyarakat. Maka siasat dalam berjejaring, membangun ruang aman, serta kampanye edukasi dan advokasi juga dilakukan dengan lebih kuat, namun juga fleksibel terhadap perkembangan suatu keadaan. Salah satu yang dilakukan oleh kelompok-kelompok subkultur ini adalah melawan dengan menawarkan narasi tanding melalui ruang digital dan media populer.

\section{METODE PENELITIAN}

Penelitian ini mendialogkan metode analisis isi kualitatif berperspektif feminis (Reinharz 2005). Pembacaan dilakukan melalui artefak budaya untuk memahami identitas kelompok marginal secara individual, kolektif, maupun interseksinya dengan kategori sosial yang lain. Artefak budaya tersebut merupakan artikulasi produk dari lini kehidupan manusia. Reinharz (2005: 202) menyebutkan bahwa subjek studi feminis salah satunya dapat dilakukan melalui narasi dan teks visual. Penelitian teks tersebut dilakukan terhadap video YouTube "Transpria Indonesia: Kami Ada, Nyata dan Berhak Juga, Bahagia. Part 1." Video tersebut dianalisis karena membahas secara komprehensif perihal kegamangan eksistensi transpria muda di Indonesia beserta tantangan harian yang mesti mereka lalui saban waktunya.

Metode analisis isi berperspektif feminis ini mengkategorikan teks-teks yang ada dalam kerangka kesetaraan gender dan mementingkan teks yang dihasilkan oleh, tentang, atau untuk kelompok tertindas (Reinharz, 2005: 201). Pada video YouTube Trans Men Talk Indonesia, teks diproduksi oleh transpria, tentang transpria dan ditujukan, khususnya, untuk transpria. Metode ini berperan dalam mengidentifikasi permasalahan transpria muda melalui perspektif, pengalaman dan perasaan mereka yang menyuarakan langsung identitasnya.

Teknik analisis isi yang dilakukan adalah dengan mendekonstruksi cara pembacaan dominan (Reinharz, 2005: 204). Cara pandang normatif dalam kerangka cisseksisme perlu dihindari untuk dapat menelisik makna-makna yang tersembunyi. Cisseksisme merupakan praktik diskriminasi terhadap individu yang mengidentifikasi dirinya berbeda dari identitas gender yang ditetapkan pada saat lahir (Teo 2014). Cisseksisme tak lain produk dari kuasa normatif yang memandang bahwa identitas dan ekspresi gender, serta karakteristik seks semata berdasar pada oposisi biner, seperti lakilaki dan perempuan, maskulin dan feminin, serta jantan dan betina. 
Pembacaan atas adanya praktik cisseksisme terhadap transpria muda di Indonesia, dilakukan dengan menganalisis kalimat-kalimat yang dilontarkan Aaron, karakter dalam video tersebut. Kalimatkalimat tersebut dielaborasi dengan realitas di Indonesia yang masih menutup ruang inklusif bagi transpria. Penelitian ini berpedoman pada pemilihan tematik teks yang disesuaikan dengan topik pembahasan yang akan dikaji. Teks yang dimaksud, selain berupa ujaran kalimat dari karakter video, juga elemen artistik lain seperti pemilihan sudut kamera, tata suara dan tata cahaya. Teks-teks video tersebut didialogkan sebagai panduan dalam memahami fenomena sosial yang timpang, yakni diskriminasi yang dialami oleh transpria muda.

\section{TEMUAN DAN PEMBAHASAN}

Video YouTube Trans Men Talk Indonesia yang berjudul "Transpria Indonesia: Kami Ada, Nyata dan Berhak Juga, Bahagia. Part 1" dianalisis dengan melakukan pemilihan narasi dan teks visual secara tematik. Topik-topik yang menjadi poin utama pembahasan meliputi persoalan transpria muda dalam (1) kehidupan kencan; (2) pekerjaan; serta (3) kelangkaan ruang aman. Proses pemaknaan dilakukan berdasar pada pemilihan-pemilihan teks yang termasuk dalam ketiga topik di atas. Berikut adalah pemaparan atas temuan yang telah dianalisis.

Kompleksitas Kehidupan Kencan Transpria Muda dan Dilema dalam Melela

Pada video YouTube Trans Men Talk Indonesia, Aaron digambarkan sedang mengisahkan kegelisahannya atas perkara romansa yang tengah ia alami kepada Gavi, teman baiknya. Pada menit 6:45, Aaron menuturkan bahwa ia memiliki janji pertemuan perdana bersama Gemma. Pada deskripsi video, dijelaskan bahwa Gemma adalah seorang perempuan yang setahun ini mewarnai kehidupan Aaron. "Saat rasanya sudah lahir dan mengada untuk Gemma; ia dibenturkan dengan ketakutannya bertemu langsung dengan gadis yang hampir satu tahun ini lalu-lalang di kehidupannya" (Trans Men Talk Indonesia 2021). Berdasar pada deskripsi tersebut, dapat ditelisik bahwa perkenalan yang terjalin antara Aaron dan Gemma berlangsung dalam ruang digital, sebab keduanya belum pernah bertemu langsung secara tatap muka.

Ketika keduanya diceritakan memutuskan untuk bertemu secara langsung, maka disitulah kebimbangan dirasakan karakter Aaron. Perasaan ragu atas eksistensinya sebagai seorang laki-laki kembali menyeruak. Berdasar video menit ke 7:20, dapat dianalisis bahwa penyebab keraguan tersebut karena Gemma belum mengenal identitas Aaron sebagai seorang transpria. Aaron digambarkan takut bila Gemma akhirnya melihat dirinya secara langsung dan memunculkan reaksi transfobia.

Kekhawatiran Aaron kian memuncak sebab ia memiliki keinginan untuk menjalin relasi intimasi terhadap Gemma. Namun dirinya masih diliputi kegelisahan bila ternyata Gemma sama seperti masyarakat lain yang mengamini bahwa gender hanya terdiri atas oposisi biner cis perempuan dan cis laki-laki saja, "gue pengen ngejalin relasi lebih sama dia. Cuman gue gak bisa ngebayangin apakah gue man enough buat dia?" (Aaron 2021). 

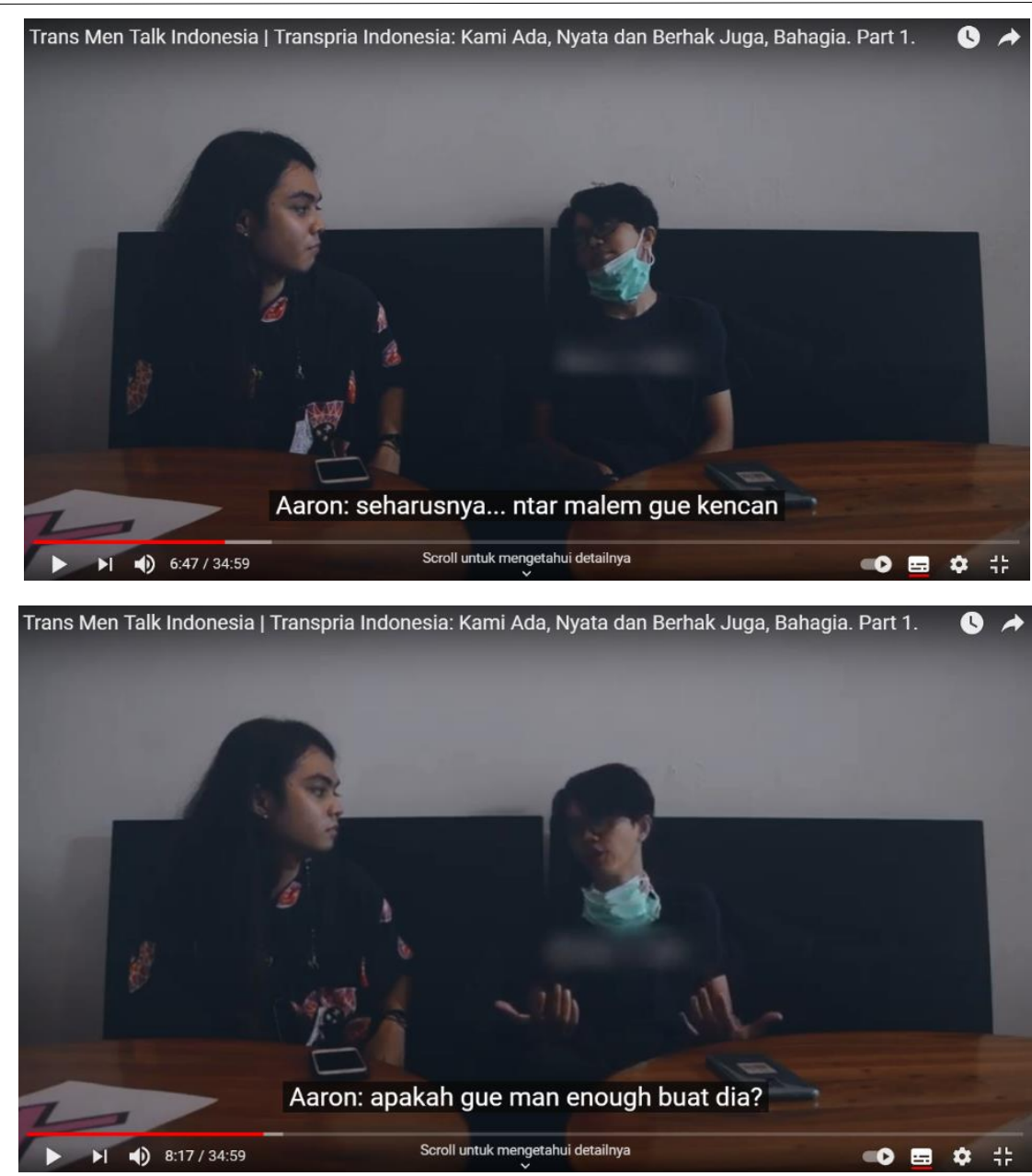

(Sumber: Video YouTube Trans Men Talk Indonesia 2021)

Gambar 1. Aaron (kanan) digambarkan sedang menceritakan kegelisahannya kepada Gavi (kiri) atas kehidupan kencannya bersama Gemma

Perasaan hendak divalidasi oleh orang lain merupakan sesuatu yang lumrah. Terlebih ketika keinginan tersebut ditujukan kepada orang-orang yang dianggap penting dan berharga bagi individu transpria muda. Internalisasi maskulinitas hegemonik menjadi sesuatu yang wajar ketika dilakukan oleh transpria. Ihwal ini terjadi sebab identitas gender merupakan serangkaian repetisi yang terusmenerus diimitasi dalam kerangka normanorma yang hegemonik pula. Karena sifatnya yang berupa performa, maka tak ada yang bisa disebut benar atau salah (Butler, 1990: 174).

Kekhawatiran Aaron atas bagaimana reaksi Gemma ketika akan bertemu dengannya secara langsung, merujuk pada kondisi fisik yang dimiliki
Aaron. Meski menghayati diri sebagai seutuhnya laki-laki, namun Aaron tak memiliki serangkaian performa yang cisnormativitas alamatkan kepada sosok yang menyandang label identitas laki-laki. Karakter Aaron yang belum atau memilih tidak melakukan transisi medis, membuat ia tak memiliki keadaan biologis seperti yang biasanya dimiliki oleh cisgender laki-laki. Kondisi fisik kasat mata, seperti kontur wajah yang tegas, pertumbuhan kumis, cambang, tipe suara yang memberat, dada yang bidang, badan yang tegap, serta pinggul yang tak besar, terepetisi sebagai sebuah penanda atas tubuh laki-laki.

Transpria memiliki kesadaran untuk memenuhi serangkaian penanda tersebut dan melakukan modifikasi tubuh untuk meneguhkan citra dirinya sebagai laki-laki 
(Rubin 2003). Maskulinitas yang diimajinasikan oleh beberapa transpria muda tumbuh karena kultur patriarki telah mengakar kuat sebelumnya. Misalnya bahwa hal-hal tentang keberanian, agresivitas, "kejantanan" adalah pola yang selalu ada pada diri laki-laki, maka transpria muda pun mengamini itu untuk mengafirmasi bahwa dirinya adalah seorang laki-laki. Meski begitu, dengan atau tidak melakukan transisi medis, diri seseorang tetap utuh dan valid sebagai apapun ia mengidentifikasikan dirinya.

Situasi inilah yang membuat beberapa transpria muda memiliki kompleksitas perasaan ketika berurusan dengan kehidupan kencan. Pada kasus Aaron yang digambarkan dalam video, ia tak mengetahui apakah Gemma adalah orang yang ramah terhadap transgender. Keadaan tersebut membuat Aaron frustasi. Pada satu sisi, ia ingin berelasi intimasi dengan orang lain, namun pada satu sisi selanjutnya, transpria muda ini harus bernegosiasi dengan proses penerimaan diri (coming in $)^{2}$ yang berlangsung terusmenerus sepanjang kehidupannya. Ia secara tak langsung diharuskan pula untuk mengungkapkan identitasnya kepada Gemma.

Pada deskripsi video, ditunjukkan bahwa Aaron mengalami dilema dan keyakinan yang belum penuh untuk mengungkapkan penghayatan paling personalnya kepada Gemma. Melela atau dikenal pula dengan sebutan coming out, merupakan proses berbagi atau pengungkapan orientasi seksual dan atau identitas gender terhadap orang lain secara sukarela dan sadar (https://lgbtqia.ucdavis.edu/educated/gloss ary). Bagi setiap individu, proses ini unik dan tidak ada panduan yang kaku atau cara

2 Coming in merupakan proses seumur hidup individu dalam menerima, mengenali, memahami dan menghayati identitas gender maupun seksualitasnya. Proses ini bersifat sangat personal yang benar dan salah dalam melela. Garvey et al. (2018: 667) mengatakan bahwa keputusan untuk mengungkap identitas seksual seseorang adalah keputusan pribadi dan dimungkinkan pula ditentukan oleh konteks eksternal. Tidak ada kewajiban bagi seseorang untuk melela, pertimbangan seperti waktu dan kondisi mental yang tepat, serta keamanan dan kenyamanan dari individu adalah yang paling penting sebelum proses melela dilakukan.

Karakter Aaron menyadari kalau ia sama sekali tak memiliki kewajiban untuk mengungkapkan identitasnya dan memberi pemahaman terhadap orang-orang tentang siapa dirinya. Namun Aaron dihadapkan pada perasaan wajib untuk melela karena ia ingin jujur dan menjadi diri sendiri ketika hendak menjalani relasi intimasi dengan orang lain. Paradoksal perasaan yang dialami oleh Aaron sebagai seorang transpria muda ini tak pernah dialami oleh kaum cisgender. Keadaan tersebut membuat transpria muda terus-menerus melakukan agensi dan negosiasi.

Kenalan yang basic
lah, udah aja, tapi
nggak bisa. Kewajiban
ini tuh, perasaan wajib
buat ngenalin identitas
itu nggak terjadi pada
laki-laki cisgender
kan? Mereka nggak
perlu kenalan tuh yang
"halo nama gue
Aaron, gender gue
laki-laki cisgender,
orientasi seksual gue
heteroseksual” nggak
ada kejadian tuh yang
begituan. Tapi kalau
identitas gue, rasanya

dan spiritual. Kondisi lingkungan seperti lingkungan yang ramah atas keragaman SOGIESC atau lingkungan yang diskriminatif dan memproduksi stigma terhadap LGBTIQ, berperan besar dalam mempengaruhi proses ini. 
gue harus melakukan

hal itu (Aaron 2021).

Transpria muda diharuskan mencari dan bahkan menciptakan peluang sendiri untuk tetap bertahan ketika ia diperlakukan "berbeda," termasuk pada ranah kehidupan yang paling intim. Perkara mengenal, berkencan dan menjalin relasi intimasi terhadap orang lain adalah satu kekhasan kehidupan kaum muda. Namun ihwal tersebut bahkan tak dapat dengan leluasa transpria muda peroleh dan rasakan. Bangunan normatif menjelma garis batas yang jelas atas keragaman gender dan seksualitas yang dikekang.

Administrasi yang Diskriminatif dan Kelangkaan Akses Pekerjaan

Pemuda memiliki serangkaian kerentanan persoalan. Posisi mereka yang tak sepenuhnya memiliki aspek kapital secara sosial maupun finansial, membuat mereka tak memiliki daya tawar yang sepadan. Pada kelompok muda yang juga merupakan kelas pekerja (working class), upaya resistensi tak lantas dapat menekan ketimpangan ekonomi yang telah terstruktur secara masif (Sutopo 2016). Kaum muda justru kian terbebankan dengan ilusi atas kebebasan dan fleksibilitas dalam lingkungan pekerjaan di era kekinian.

Standing (dalam Darmawan et al. 2019) mengungkapkan bahwa pemuda menduduki kelompok terbanyak dalam mengisi kelas sosial pekerja prekariat. Kenyamanan ilusi atas waktu kerja yang tak pasti justru mengukuhkan kerentanan yang dialami kaum muda sebagai pekerja. Hal ini dapat ditinjau dari ketiadaan jaminan kesehatan maupun keselamatan kerja, ketiadaan pembagian kerja (job

\footnotetext{
${ }^{3}$ Deadname atau "nama mati" mengacu pada nama yang diberikan oleh orang lain terhadap individu trans (Haimson et al. 2016). Deadname tidak diungkapkan kepada orang lain kecuali individu trans sendiri yang menghendakinya. Memaksa individu trans untuk memakai nama yang bukan
}

description) yang jelas, serta "fleksibilitas" tempat kerja yang bisa dilakukan di mana saja. Keadaan tersebut membuat kaum muda pekerja rentan untuk dijadikan subjek eksploitasi semata (Darmawan et al. 2019: 49). Namun wacana kerentanan pemuda dalam pasar kerja, memiliki celah yang abai pada interseksinya dengan kategori sosial yang lain, yakni gender minoritas.

Transpria sebagai salah satu gender yang tak dilegitimasi di Indonesia, memiliki kerentanan berlapis ketika hendak berurusan dengan dunia kerja. Bahkan untuk bisa masuk dan "merelakan" diri menjadi tenaga kerja yang dieksploitasi, transpria muda tidak mendapatkan kesempatan itu. Ihwal ini dikarenakan mereka tak memiliki dokumen-dokumen administrasi yang kerap menjadi persyaratan masuk ke perusahaan. Dokumen kenegaraan seperti KTP dan KK (Kartu keluarga) mencantumkan nama lahir ${\text { (deadname })^{3}}^{3}$ serta jenis kelamin yang bukan milik transpria. Begitu pula dengan ijazah sekolah, CV (Curriculum Vitae) maupun SKCK (Surat Keterangan Catatan Kepolisian) yang turut menjadi ketentuan persyaratan untuk mendaftar pekerjaan.

Matteo Aaron dalam video YouTube Trans Men Talk Indonesia mengalami diskriminasi tersebut. Sebagai transpria muda, ia tak memiliki "pengakuan" dari negara bahwa dirinya eksis sebagai warga negara Indonesia. Ketiadaan validasi dari negara atas penghayatan identitasnya, berimplikasi pada banyak hal dalam hidupnya.

Gue dari lahir gak
diakuin di Indonesia.
Gue gak punya tuh
dokumen-dokumen

miliknya, atau bahkan mengungkapkan deadname individu trans (outing) merupakan praktik kekerasan seksual. Bertanya mengenai "nama asli" individu trans adalah sesuatu yang tidak inklusif, sebab "nama asli" individu trans adalah nama yang saat ini ia gunakan, bukan nama yang tercantum pada identitas kenegaraan. 
resmi saat gue lahir.

Gue harus meranin orang lain. Kehidupan orang lain. Gue harus meranin orang lain di depan pegawai pemerintahan kalau mau urus KTP dan segala macem. Gua harus meranin orang lain kalo gue sakit dan harus ke rumah sakit. Bahkan pas gue kuliah... gue harus jadi orang lain dulu, gak jadi diri sendiri. Gue tuh warga negara Indonesia, udah sesuai tatanan UndangUndang. Tapi gue belum punya dokumen resmi Indonesia. lo nyari Matteo Aaron kagak ada di Indonesia. Univ tempat gue kuliah juga kagak

ada nama gue di sana. Ini karena gue gak punya kartu identitas. Gue gak ada. Gue gak eksis. Gak eksis secara teknis (Aaron 2021).

Karakter Aaron menyebut identitas yang ada dalam dokumen-dokumen administrasi yang ia miliki sebagai "orang lain," sebab ia tak pernah mendaku diri sebagai nama yang ada di kartu. Jenis kelamin yang tertera juga tak merujuk pada identitas gender yang Aaron hayati sebagai laki-laki atau transgender pria. Namun struktur kuasa yang tak berpihak terhadap transgender, membuat Aaron harus berperan menjadi orang lain seumur hidupnya. Lingkungan masyarakat menjauhkan transpria muda dari dirinya sendiri. Mereka dipaksa untuk merepresi penghayatan atas identitasnya tiap hendak berurusan dengan hal-hal yang mensyaratkan penunjukan dokumen kenegaraan.

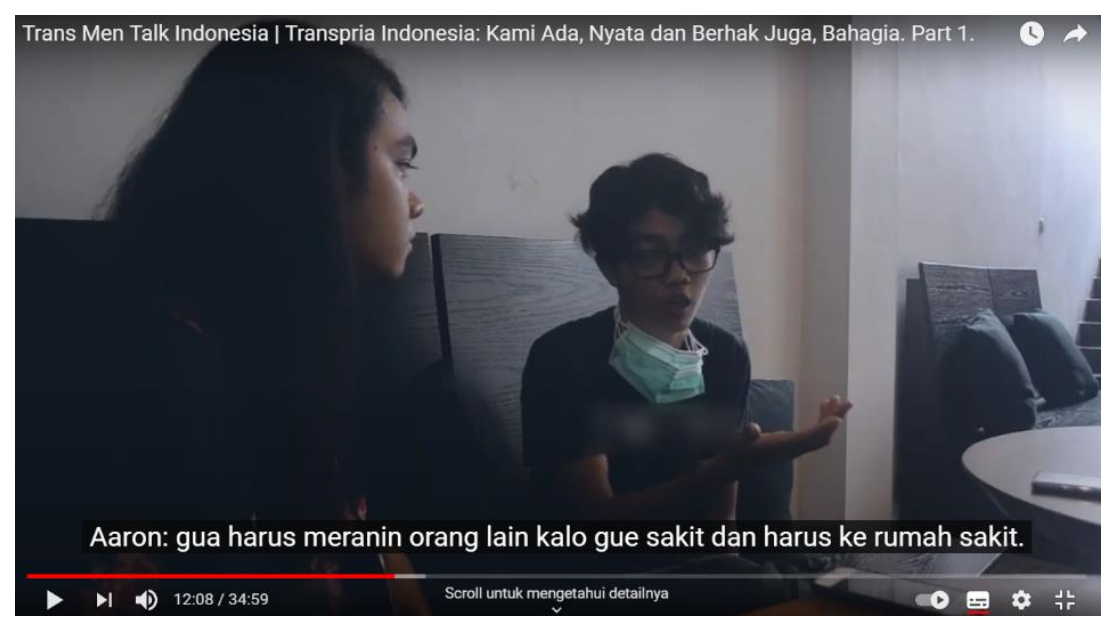




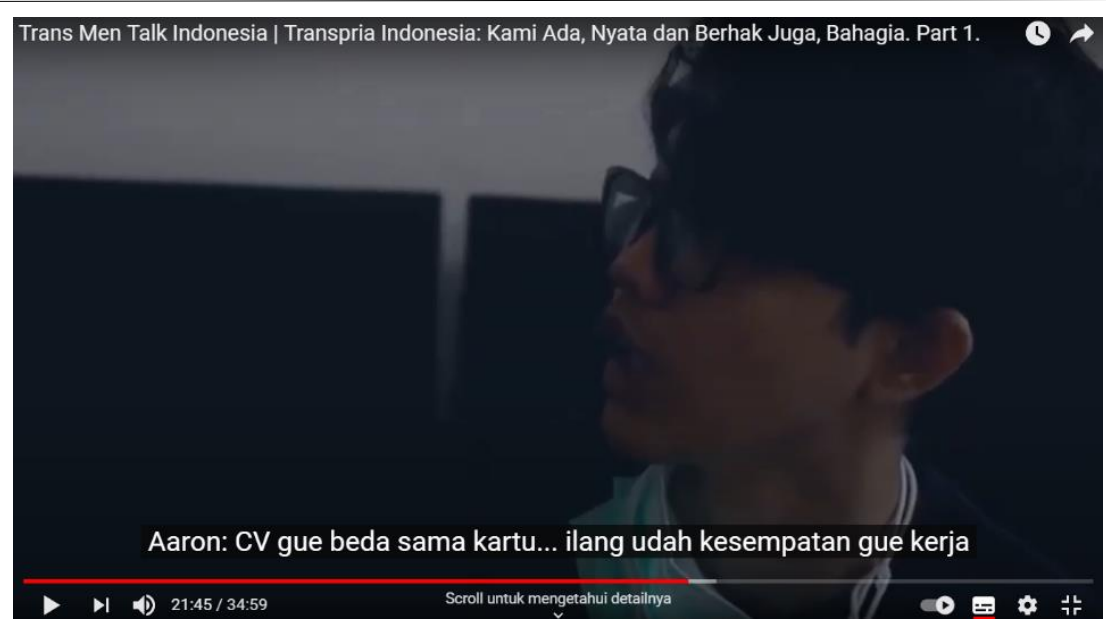

(Sumber: Video YouTube Trans Men Talk Indonesia 2021)

Gambar 2. Karakter Aaron sedang mengisahkan kesusahannya dalam mencari pekerjaan. Ia dihadang dengan sederetan persoalan struktural dan administrasi negara yang diskriminatif

Pada adegan ini, pengambilan sudut kamera diperlihatkan berfokus pada penggambaran detail (close up) ekspresi serta gestur karakter, seperti gerak tangan. Posisi ini menunjukkan bahwa Aaron sedang berbicara mengenai sesuatu yang sangat personal, yang telah menimpanya selama berkali-kali, yakni diskriminasi yang ia alami ketika berhadapan dengan perkara administrasi. Ketidakadilan berbasis gender dalam ranah pekerjaan, berimplikasi pada keberlanjutan hidup dan kondisi ekonomi transpria muda. Ketika kemandirian finansial belum stabil diperoleh, maka kerentanan diskriminasi pun kian tinggi. Bahkan ketika transpria muda telah berhasil masuk dalam lingkungan pekerjaan, praktik transfobia tak bisa seketika lenyap. Pelbagai peliyanan dan kekerasan tetap mengancam transpria muda ketika tempat kerjanya bukanlah ruang aman bagi manusia dengan ragam gender non-hegemonik.

Arus Pelangi (2017: 30) mencatat bahwa selain pembatasan akses memperoleh pekerjaan yang layak, individu LGBTIQ, termasuk di dalamnya transpria, mengalami pembatasan cara berpakaian, berekspresi, peningkatan karir, hingga pemecatan. Penelitian yang dilakukan Arus Pelangi di delapan provinsi di Indonesia menyebutkan bahwa 45 persen subjek terpaksa bekerja pada ranah informal, paruh waktu, maupun pada industri kreatif dan jasa. Penelitian yang sama juga menunjukkan bahwa tingkat pengangguran yang dihadapi komunitas queer mencapai 17 persen (2017: 30).

Diskriminasi dalam ranah pekerjaan serta praktik invalidasi yang dilakukan negara terhadap transpria, dimungkinkan bisa disiasati melalui transisi legal atau transisi identitas resmi. Pergantian data yang dapat diubah adalah nama dan jenis kelamin. Prosedur tersebut termaktub dalam Undang-Undang Nomor 23 Tahun 2006 tentang Administrasi Kependudukan. Namun hal tersebut bukan pula tanpa hambatan. Pada proses pergantian nama, individu transpria harus memenuhi serangkaian persyaratan seperti memiliki saksi dari pihak keluarga dan rekan terdekat (Persatuan Priawan Indonesia 2018). Sementara tidak semua individu transpria berada di tengah lingkungan kerabat yang suportif atau memiliki lingkungan perkawanan yang inklusif. Meski tak memerlukan pengacara serta saksi dari pihak medis, kewajiban menghadirkan saksi merupakan persyaratan yang berat bagi komunitas transpria.

Saksi dari pihak medis diperlukan untuk melakukan pergantian jenis kelamin di kartu identitas. Namun bunyi pasal yang 
tidak eksplisit yang mengatur tentang perubahan jenis kelamin, membuat persyaratan di tiap wilayah menjadi berbeda-beda. Pada Undang-Undang Nomor 23 Tahun 2006 disebutkan bahwa "yang dimaksud dengan "Peristiwa Penting lainnya" adalah peristiwa yang ditetapkan oleh pengadilan negeri untuk dicatatkan pada Instansi Pelaksana, antara lain perubahan jenis kelamin" (pasal 56 ayat 1). Frasa "peristiwa penting" diinterpretasikan secara sepihak seturut kuasa Pengadilan Negeri yang berwenang di suatu wilayah tertentu. Persatuan Priawan Indonesia (2018: n.p) mencatat bahwa beberapa pengadilan bahkan mensyaratkan adanya operasi rekonstruksi penis untuk dapat mengganti jenis kelamin pada kartu identitas. Namun ada pula pengadilan yang tak mensyaratkan transpria harus melakukan transisi medis dahulu, misalnya tindakan terapi hormon (hormone replacement therapy), sebelum mengajukan transisi legal. Terkadang beberapa pengadilan juga mengajukan persyaratan tambahan, seperti harus menghadirkan pemuka agama (pendeta, ulama, dan lain-lain) sebagai saksi ahli.

Bias-bias kepercayaan mayor dan ideologi normatif yang masih mengakar pada petugas pengadilan, membuat proses transisi legal kerap berjalan alot. Tak hanya itu, stigma yang melekat sebagai bagian dari komunitas queer, membuat individuindividu transpria dimungkinkan memperoleh pelayanan yang tak ramah. Mereka rentan mendapat ujaran kebencian, intimidasi, dan bentuk kekerasan lainnya selama proses persidangan.

Proses pergantian identitas juga memakan tempo waktu yang tak sedikit. Proses persiapan mengharuskan transpria bolak-balik menemui petugas pengadilan maupun saksi ahli yang transfobik. Mereka juga diharuskan menyiapkan kronologi kasus yang akan diceritakan selama prapersidangan, hari persidangan, hingga pasca-persidangan. Pada sebagian transpria, proses ini sangat melelahkan dan menyita banyak tenaga, bahkan menimbulkan memori traumatik. Ketentuan pergantian identitas yang disyaratkan, tak lain menegasikan perasaan transpria sebagai seseorang yang mengalami langsung proses penghayatan identitasnya. Bahkan untuk divalidasi sebagai diri sendiri, transpria harus mencari "orang lain" yang disebut sebagai "saksi ahli." Mereka tidak bisa menjadi saksi atas perasaan dan pengalaman ketubuhannya sendiri.

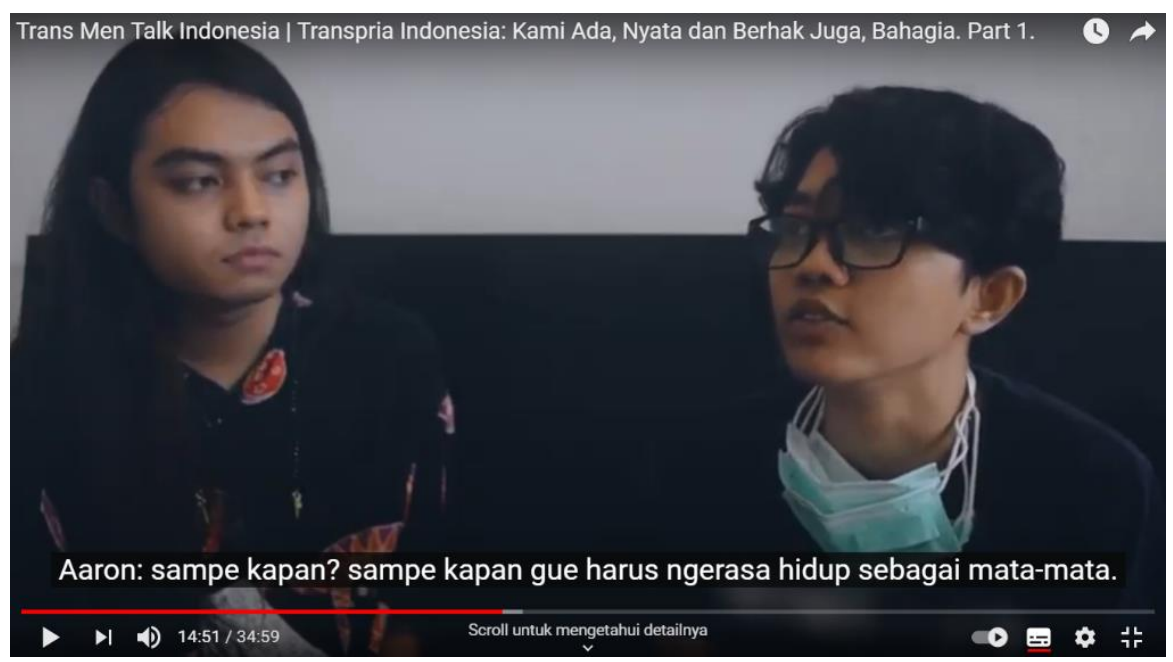




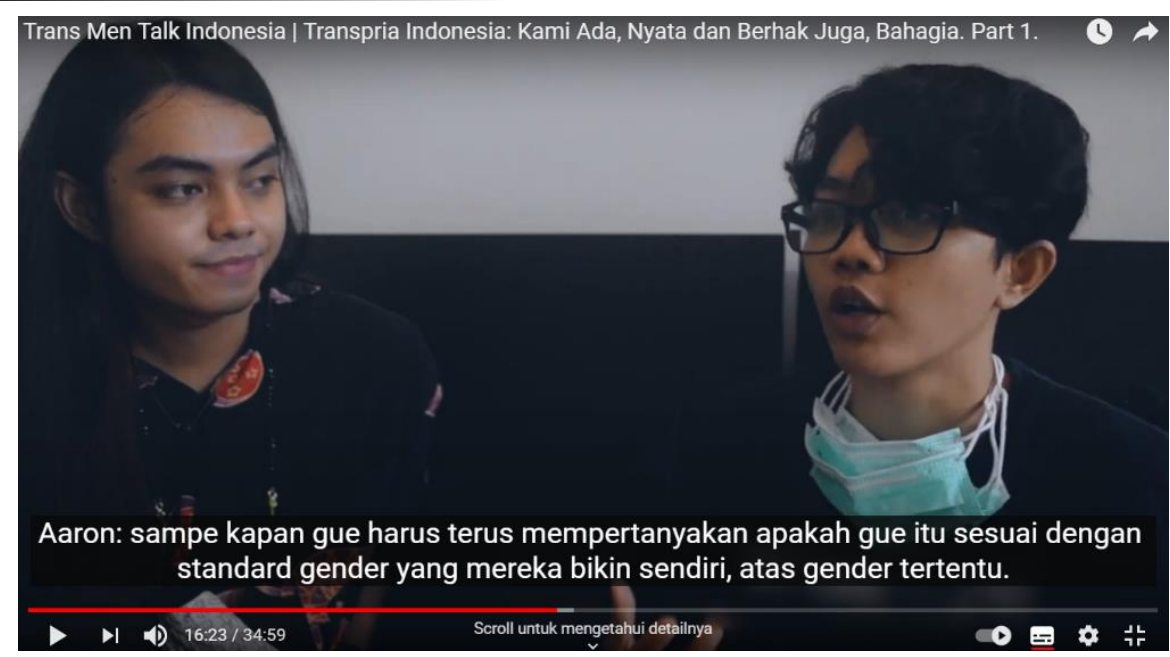

(Sumber: Video YouTube Trans Men Talk Indonesia 2021)

Gambar 3. Karakter Aaron sedang mempertanyakan keadaan struktural yang tak pernah berpihak dan mengakui eksistensinya.

Agensi transpria dalam memperjuangkan transisi legal, membuat mereka mesti menukarnya, selain dengan persiapan fisik, finansial, dan strategi berkomunikasi serta bernegosiasi dengan para petugas, juga persiapan mental yang terus-menerus kuat. Kondisi ini tentu memiliki efek yang berbeda-beda ketika dialami oleh masing-masing individu. Oleh sebab itu, tak sedikit transpria muda yang belum atau memilih tidak melakukan transisi legal. Komunitas marginal ini pada akhirnya tetap harus berjuang di tiap-tiap keadaan yang mengharuskan mereka menunjukkan dokumen kenegaraan yang bukan merupakan miliknya. Bernegosiasi dalam mendapatkan pekerjaan meski lampiran kartu identitasnya tak mencantumkan nama yang mereka sendiri kehendaki. "Sampe kapan gue harus hidup sebagai mata-mata?" (Aaron 2021). Sebab cisnormativitas tak menawarkan ruang pada mereka yang beragam, dalam video tersebut, Aaron menganalogikan dirinya serupa "mata-mata." Tak memiliki identitas resmi yang dilegitimasi negara. Meski dirinya ada, perasaan serta pengalamanya nyata, suaranya tetap senyap, kehadirannya lenyap, tanpa pernah tercatatkan sejarah.

Ruang Aman yang Sukar Ditemukan
Ruang aman memiliki multiplisitas makna. Ia dapat berarti spasial ruang yang merujuk pada letak geografis atau berupa tempat yang dapat dihuni. Namun ruang aman bisa pula merujuk pada proses laku hidup dan cara pandang. Ihwal tersebut dapat berwujud melalui aturan dan kebijakan alternatif, tafsir kepercayaan yang progresif, karya seni yang inklusif, dan lain-lain. Ruang aman dapat pula berkelindan dalam hubungan komunikasi antar-manusia, dalam lingkungan kekerabatan, perkawanan, maupun melalui institusi sekolah, kampus, pekerjaan, dan sebagainya. The Roestone Collective (dalam Hartal 2017) memaparkan ruang aman sebagai konsep hidup yang memiliki beragam variasi disesuaikan dengan berbagai konteks yang ada. Pada konteks kajian queer, Hartal (2017: 1) menuturkan bahwa ruang aman adalah sesuatu yang terlindungi dan inklusif, di mana tiap orang bebas mengekspresikan identitasnya dengan perasaan nyaman.

Pada video YouTube Trans Men Talk Indonesia, perkara ruang aman juga menjadi pembahasan serius yang dibicarakan oleh Aaron dan Gavi. Sebagai transpria muda, Aaron merasakan bahwa dirinya belum menemu ruang aman tiap kali berinteraksi dengan orang lain maupun berada di ruang publik. Cara seseorang 
dalam memperhatikan dan menatap orang lain dimungkinkan merupakan suatu hal yang sederhana, namun tidak halnya bagi transpria. Tatapan aneh yang meliyankan serta mengisyaratkan pandangan transfobik, membuat transpria mengalami kekhawatiran, ketakutan dan menimbulkan perasaan sakit. Kehadirannya seolah diinvalidasi dan eksistensinya dipertanyakan, sehingga perasaan tidak aman dan tidak nyaman kemudian muncul dari dalam diri transpria.
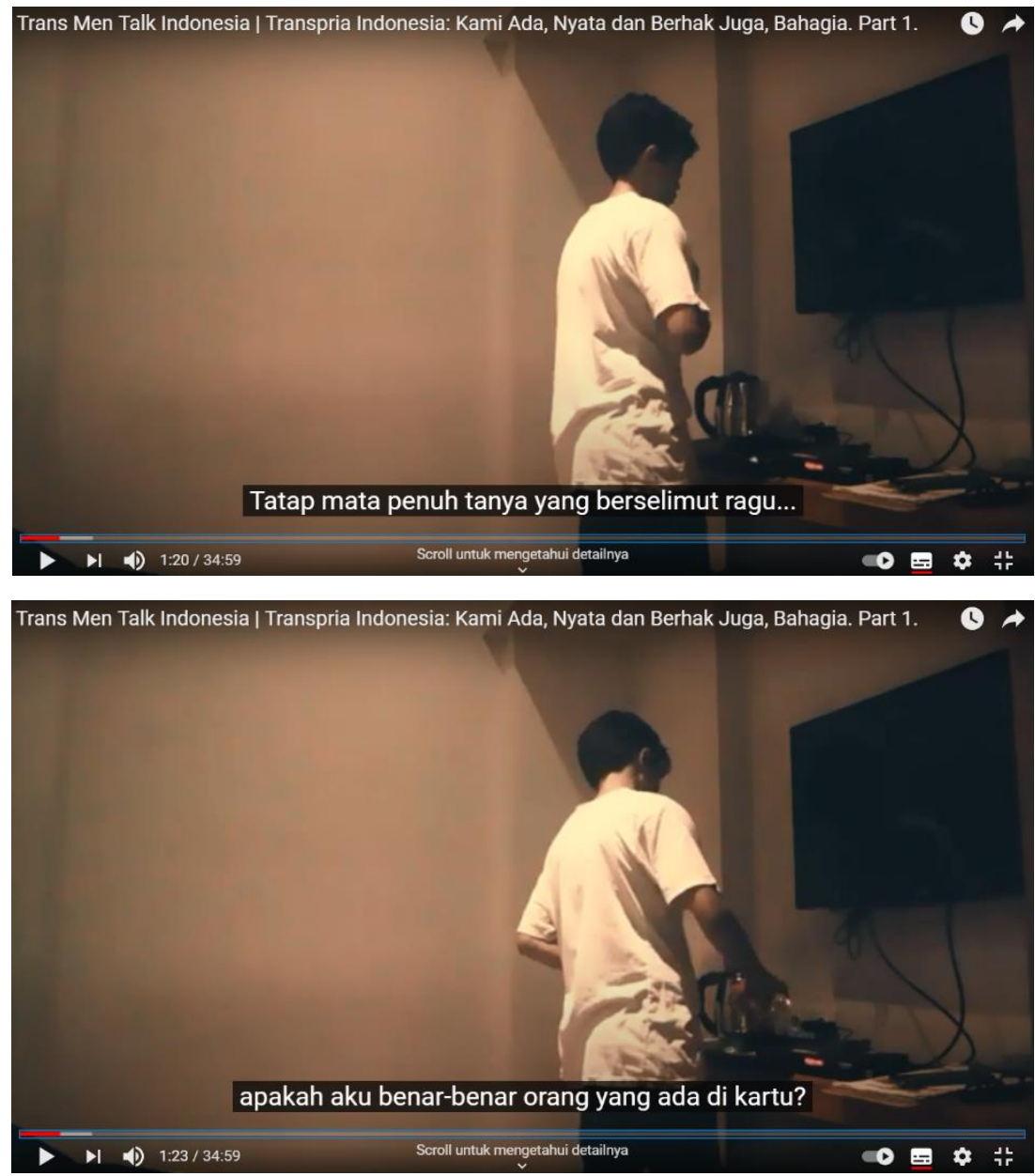

(Sumber: Video YouTube Trans Men Talk Indonesia 2021)

Gambar 4. Kisah Aaron saat harus menghadapi tatapan transfobia yang dialamatkan pada dirinya

Pada adegan awal video, digambarkan Aaron sedang berada pada sebuah kamar hotel tempat ia menginap di Jakarta. Penataan cahaya yang redup seolah ingin menunjukkan perasaan murung dan tak bersemangat yang tengah dirasakan Aaron. Dikisahkan bahwa Aaron baru saja melakukan registrasi penginapan. Namun ia harus menunjukkan dua kartu identitasnya hanya agar urusannya lebih dimudahkan, gestur tersebut dapat ditinjau pada menit ke 1:05. Pada narasi yang dilontarkan Aaron selanjutnya, diketahui bahwa ia harus menghadapi tatapan transfobia dan menerima misgendering dari petugas penginapan karena ekspresi gendernya tak sesuai dengan apa yang tertera di kartu identitasnya.

Selain tatapan transfobia yang kerap dialamatkan terhadap transpria, praktik kekerasan lain yang sering transpria peroleh adalah misgendering. Paterson (2019: 4) menjelaskan bahwa misgendering merupakan praktik ketika seseorang dideskripsikan maupun dipanggil dengan 

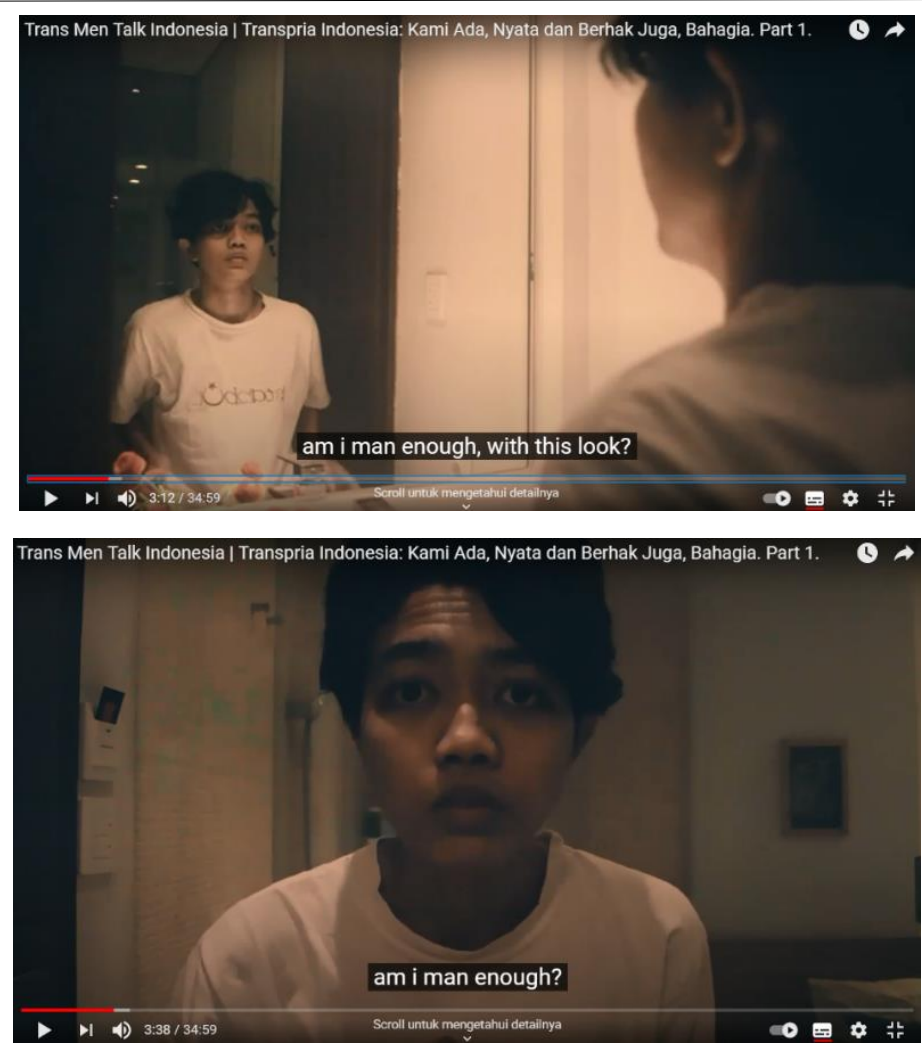

(Sumber: Video YouTube Trans Men Talk Indonesia 2021)

Gambar 5. Aaron mempertanyakan kepada dirinya, apakah ia "telah cukup" menjadi laki-laki

Perasaan tidak aman dan tidak nyaman tersebut, digambarkan terbangun melalui latar musik yang penuh dimainkan, mulai pada menit ke 2:30 sampai menit ke 3:10. Pemilihan nada suara yang bernuansa gelap nan suram, menggambarkan suasana Aaron yang tampak muram. Digambarkan bahwa karakter Aaron menunjukkan gestur tubuh yang sedang kacau, sedih, namun juga marah. Ketiadaan ruang aman yang ia miliki, berimplikasi pada invalidasi terhadap diri sendiri. Ihwal ini dituturkan mulai pada menit ke 3:11 saat Aaron mempertanyakan dirinya sendiri. Sembari menghadap cermin dan memandang pantulan atas refleksi tubuhnya, Aaron berujar, "am I man enough, with this look? am I man enough, with this voice? Am I man enough, with this kind of face? Am I man enough, with this body? Am I man enough? (Aaron 2021). Pertanyaan-pertanyaan tersebut muncul sebab cisnormativitas selalu menekan transpria untuk tunduk pada norma-norma ideal tentang tubuh fisik lakilaki.

Pada video tersebut, Matteo Aaron, dengan segala yang ia punyai, berjuang melawan ketakutannya atas identitasnya yang kerap dianggap tak jelas. Penciptaan ruang-ruang aman yang berperspektif SOGIESC akan mengakomodasi kita dalam memahami, bahwa karakteristik seks maupun ekspresi gender seseorang tak memiliki keterkaitan dengan identitas gendernya. Mereka yang terlahir dengan kondisi biologis yang kerap diasosiasikan dengan tubuh perempuan, tak bisa dengan serta merta masyarakat sematkan label sebagai seorang perempuan. Sebab identitas gender adalah identifikasi pribadi yang didasari pada perasaan yang sangat personal (Arus Pelangi 2017), maka siapapun berhak untuk menjadi dirinya sesuai dengan apa yang ia hayati. Tidak ada yang "telah cukup" sebab tidak ada batas yang kaku untuk "menjadi” gender tertentu. 
Selama diri meyakini sebagai laki-laki, maka ia adalah laki laki. Begitu pula dengan karakter Aaron, serta para transpria muda lainnya, mereka juga sepenuhnya laki-laki, yang valid dan utuh sebagai manusia.

$\begin{array}{lrr}\text { SIMPULAN: } & \text { TRANSPRIA } & \text { ADA, } \\ \text { NYATA DAN } & \text { BERHAK } & \text { JUGA } \\ \text { BAHAGIA } & & \end{array}$

Perbincangan seputar kaum muda perlu juga melihat interseksinya dengan kategori-kategori sosial yang lain, salah satunya adalah identitas gender. Ketika pisau analisis menawarkan ruang pada permasalahan pemuda dari identitas di luar dominasi biner gender, maka terbaca pula lapisan kerentanan yang harus dihadapi oleh pemuda. Trans Men Talk Indonesia melalui videonya "Transpria Indonesia: Kami Ada, Nyata dan Berhak Juga, Bahagia. Part 1," mengisahkan dengan organik, diskriminasi yang dilalui oleh transpria muda di Indonesia. Ruang-ruang artikulasi diri semacam ini penting di tengah kontestasi wacana mayor yang kerap luput memusatkan perspektif kepada kelompok yang suaranya dibungkam dan bahkan dihilangkan.

Transpria muda Indonesia memiliki kekhasan permasalahan yang kurang lebih serupa dengan kaum muda Indonesia yang lain. Kompleksitas dalam membangun relasi intimasi, dalam bertahan dan melawan sistem pasar kerja, serta ruang aman yang tak sepenuhnya bisa didapatkan, adalah situs-situs yang menjadi bagian dari perjuangan pemuda. Namun diskriminasi yang dirasakan oleh transpria muda bisa dimungkinkan sangat berbeda. Ihwal ini terjadi karena mereka tak hanya sebagai bagian dari kelompok muda, melainkan juga kelompok marginal berbasis gender. Struktur sosial yang berkiblat pada cisnormativitas, merepresi mereka untuk jauh tak tersentuh. Diskriminasi yang dialami tak terdengar, agensi yang dilakukan juga tak jadi perhatian. Sebab eksistensi mereka tak divalidasi, bahkan dianggap tidak ada.

Ketidakadilan yang menimpa kehidupan transpria muda bukanlah persoalan personal, melainkan perkara struktural. Maka solidaritas kolektif bagi komunitas ini merupa urgensi. Ruangruang inklusif bisa mulai diciptakan agar mereka yang diliyankan merasa tak sendiri dan perjuangan mereka selama ini memiliki arti. Ruang aman bisa pula berwujud dalam bentuk tulisan dan publikasi ilmiah. Limitasi dari penelitian ini yang hanya menganalisis satu video dari Trans Men Talk Indonesia, bisa dilengkapi dengan mengkaji video-video maupun kegiatankegiatan Trans Men Talk Indonesia yang lain dengan topik seputar transpria yang juga beragam. Penelitian ini memiliki keterbatasan, yakni hanya merekam diskriminasi yang dialami oleh transpria muda. Pada kajian selanjutnya, peneliti menyarankan adanya ekplorasi lebih dalam terkait dengan agensi komunitas transpria muda dalam melawan cisnormativitas. Dengan aktif melakukan kajian dan membangun wacana yang inklusif tentang transpria muda, maka diharapkan kian banyak yang turut belajar mendengar keragaman pengalaman komunitas trans. Sebab serupa manusia yang lainnya, transpria ada, nyata, dan berhak juga bahagia.

$* * * * *$ 


\section{DAFTAR PUSTAKA}

Agustine, Sri, Evi Lina Sutrisno, dan Dewi Candraningrum. 2015. "Diri, Tubuh dan Relasi: Kajian atas Transgender FTM (Female to Male) di Jakarta." Jurnal Perempuan, 20 (4): 48-74.

American Psychiatric Association. 2013. Diagnostic and Statistic Manual of Mental Disorder Fifth Edition (DSM$V)$. London: American Psychiatric Association.

Ardiansyah, Abhipraya. 2015. "Transmen Camp \#2: Kembali ke Rumah.” Suara Kita. Retrieved April 29, 2021. (http://www.suarakita.org/2015/09/tr ansmen-camp-2-kembali-ke-rumah/).

Arus Pelangi. 2017. Modul Pendidikan Dasar SOGIESC. Jakarta: Federasi Arus Pelangi.

Butler, Judith. 1990. Gender Trouble: Feminism and the Subversion of Identity. New York: Routledge.

Collier, Megan, dan Meghan Daniel. 2019. "The Production of Trans Illegality: Cisnormativity in the U.S. Immigration System." Sociology Compass 13(4):e12666. doi: 10.1111/soc4.12666.

Darmawan, Arif Budi, Faishal Abdul Azis, dan Mei Nurul Aini. 2019. "Negosiasi Pemuda dalam Fleksibilitas Pasar Kerja: Studi Netnografi terhadap Mikro-Selebriti di Daerah Istimewa Yogyakarta." Jurnal Studi Pemuda, 8(1):47. doi: 10.22146/studipemudaugm.45231.

Firmansyah, Deri Eka, Aquarini Priyatna dan Lina Meilinawati Rahayu. 2018. "Representasi Tubuh Transman dalam Film 3 Generations." Metahumaniora, 8(2): 179-192.

Garvey, J. C., Matsumura, J. L., Silvis, J. A., Kiemele, R., Eagan, H., \& Chowdhury, P. 2018. "Sexual Borderlands: Exploring Outness
Among Bisexual, Pansexual, and Sexually Fluid Undergraduate Students." Journal of College Student Development, 59(6), 666-680. https://doi.org/10.1353/csd.2018.006 $\underline{4}$

Haimson, Oliver L., Jed R. Brubaker, Lynn Dombrowski, dan Gillian R. Hayes. 2016. "Digital Footprints and Changing Networks During Online Identity Transitions." Proceedings of the 2016 CHI Conference on Human Factors in Computing Systems. San Jose California USA: ACM. Pp. 2895-2907.

Hartal, Gilly. 2017. "Fragile Subjectivities: Constructing Queer Safe Spaces." Social \& Cultural Geography 1-20. doi: 10.1080/14649365.2017.1335877.

Hayfield, Nikki. 2020. Bisexual and Pansexual Identities: Exploring and Challenging Invisibility and Invalidation. New York: Routledge.

Human Rights Watch. 2016. "Permainan Politik Ini Menghancurkan Hidup Kami”: Kelompok LGBT Indonesia dalam Ancaman. New York: Human Rights Watch.

LGBTQIA Resource Center. "LGBTQIA Resource Center Glossary." University of California, Davis Campus. https://lgbtqia.ucdavis.edu/educated/ glossary.

Lovelock, M. 2017. “I am....”: Caitlyn Jenner, Jazz Jennings and the Cultural Politics of Transgender Celebrity." Feminist Media Studies, 17(5): 737754.

https://doi.org/10.1080/14680777.20 17.1298649

National LGBT Health Education Center. "Glossary of Terms for Health Care Teams.” Retrieved April 1, 2021. 
O’Neill, Matthew G. 2014. “Transgender Youth and YouTube Videos: SelfRepresentation and Five Identifiable Trans Youth Narratives." Queer Youth and Media Cultures, Pp. 34-45. UK: Palgrave Macmillan.

Paterson, Nicole. 2019. LGBTIQA+ Communities: Glossary of Common Terms. Australia: The Child Family Community Australia.

Persatuan Priawan Indonesia. 2018. Mengenal Trans Laki-Laki. Jakarta: Persatuan Priawan Indonesia.

Pullen, Christopher, ed. 2014. Queer Youth and Media Cultures. UK: Palgrave Macmillan.

Pyne, Jake. 2011. "Unsuitable Bodies: Trans People and Cisnormativity in Shelter Services." Canadian Social Work Review, Pp. 129-137. https://www.jstor.org/stable/4165883 $\underline{8}$.

Raun, Tobias. 2016. Out online. Trans Selfrepresentation and Community Building on YouTube. Routledge.

Reinharz, Shulamit. 2005. Lisabona Rahman dan J. Bambang Agung, Penerj. Metode-metode Feminis dalam Penelitian Sosial. Jakarta: Women Research Institute.

Rubin, Henry. 2003. Self-made Men: Identity, Embodiment, and Recognition among Transsexual Men. Nashville: Vanderbilt University Press.

Setyono, Vania Sharleen. 2016. "I Post Therefore I am" Sebuah Kajian
Budaya Populer tentang Social Media dan Visibilitas Transgender Female to Male (Transman) di Ruang Publik. Retrieved Maret 30, 2021. https://www.academia.edu/31114667 /Visibilitas_Transman_Indonesia_da $\underline{\text { n_Media_Sosial_Kajian_Teologis_d }}$ $\underline{\text { an_Budaya_Populer }}$

Shean, Ino. 2020. "Lihat Lebih Dekat Transmen Indonesia." Qbukatabu. Retrived April 29, 2021. (https://qbukatabu.org/2020/12/17/li hat-lebih-dekat-transmenindonesia/).

Sutopo, Oki Rahadianto. 2018. "Pemuda dan Resistensi: Sebuah Refleksi Kritis." Jurnal Studi Pemuda, 5(2): 502. doi: 10.22146/studipemudaugm.37954.

Teo, Thomas, ed. 2014. Encyclopedia of Critical Psychology. New York: Springer.

Tortajada, Iolanda, Cilia Willem, R. Lucas Platero Méndez, dan Núria Araüna. 2020. "Lost in Transition? Digital Trans Activism on Youtube." Information, Communication \& Society 1-17. doi: 10.1080/1369118X.2020.1797850.

Undang-Undang Nomor 23 Tahun 2006 tentang Administrasi Kependudukan

YouTube Trans Men Talk Indonesia. Transpria Indonesia: Kami Ada, Nyata, dan Berhak Juga, Bahagia. Part

1. https://www.youtube.com/watch?v= ousZ_RiGsQA\&t=467s 